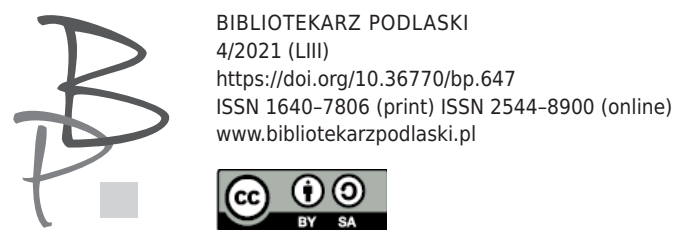

Magdalena Budnik*

Uniwersytet w Białymstoku, Polska / University of Białystok, Poland

ORCID: 0000-0003-0133-1568

\title{
Antoni Słonimski w aktach cenzury PRL. Wybór dokumentów Głównego Urzędu Kontroli Prasy, Publikacji i Widowisk z lat 1961-1980
}

Antoni Słonimski in the censorship files of the People's Republic of Poland.

A selection of documents from the Main Office for the Control of Presentations and Public Performances dated 1961-1980

Abstract: The examples of documents of the Main Office for the Control of Presentations and Public Performances (GUKPIW) quoted in the article show the censorship strategies towards Słonimski. Interestingly, in this case the most controversial - from the point of view of GUKPPiW - were not the works of this writer, but his figure. This is particularly evident in the materials from 1976, after the death of the author of Alarm. As a result of the previously binding "entry" on the poet, only reprinting of the Polish Press Agency (PAP) communiqué was allowed. The censorship's attitude to Słonimski is undeniably illustrated by the types of interference - the author was perceived as an undesirable, controversial figure, whose courageous actions - not least in the fight for freedom of speech in Poland - should not

* Magdalena Budnik - dr, adiunkt w Katedrze Badań Porównawczych i Edytorstwa Zakładzie Badań Filologicznych nad Cenzurą PRL Uniwersytetu w Białymstoku; autorka m.in. monografii Ksiązka Nowego Czytelnika. Literatura dla bytych analfabetów przeszkolonych w Polsce w latach 1948-1951 (2014). 
be reminisced. Mentions in the texts - potentially referring to the political context - were removed. Censorship was very meticulous: single words or whole sentences were cut out, and when it was not possible to "neutralise" the meaning of the text in this way - the whole thing was not allowed to be printed. Unfortunately, this way considerably impaired the reception of Słonimski.

Keywords: Słonimski, censorship of communist Poland, archives, $20^{\text {th }}$-century literature, poetry.

\section{Wstęp}

Okres wojennego wychodźstwa oraz kolejne lata w Londynie złożyły się na ponad dekadę spędzoną poza granicami Polski. Po tym okresie Antoni Słonimski w roku 1951 zdecydował wraz żoną, Janiną Konarską, o powrocie na stałe do kraju. Nie była to decyzja prosta i na pewno niejednoznaczna w ocenie. Warto w tym miejscu przywołać kilka głosów. Adam Michnik podkreślał: „Pan Antoni, uznając, że dla niego emigracja jest drogą donikąd, i wracając do Polski, zakłamał siebie, żeby móc funkcjonować”. Z kolei Ryszard Matuszewski wspominał: „Od razu po jego przyjeździe mówiło się, że to nie jest człowiek na »tak«". Według Czesława Miłosza Słonimski został do powrotu zmuszony, bowiem będąc wydawcą ,Nowej Polski”, znalazł się na emigracyjnych indeksach i był zdany na współpracę z komunistyczną władzą w Polsce ${ }^{2}$. Anna Trzeciakowska z kolei pisała:

Decyzja Antoniego o powrocie w najgorszym czasie oczywiście budziła niechęć, zwłaszcza tych środowisk, których przedstawiciele ciągani byli na przesłuchania lub siedzieli w więzieniach, na przykład AK-owcy. Sądzę, że powrót Antoniego wynikał z konieczności, i miał on poczucie, że wraca na tarczy³.

Sam Słonimski w roku 1957 wspominał czas, kiedy zdecydował się na powrót:

1 J. Kuciel-Frydryszak, Heretyk na ambonie, Warszawa 2012, s. 204-205.

2 Tamże, k. 201.

3 Tamże. 
Pytano mnie się wtedy: - Czy to prawda, że pan wrócił na dobre? - Dlaczego zaraz na dobre? Powiedzmy na średnie. A raczej na dobre i na złe - odpowiedziałem.

Nie wiem, co jeszcze zdarzyć się może, co nam los przyniesie, ale wiem, że decyzja powrotu do kraju była słuszna. Warto było godzić się na drobne kompromisy, doznawać upokorzeń i rozczarowań, aby walczyć i walczyć w Warszawie, aby do przywiązania serdecznego dołączyło się to uczucie dumy, które odczuliśmy w dniach warszawskiego października ${ }^{4}$.

W świetle tak widzianych motywów powrotu, zrozumiałymi stają się działania poety po przyjeździe do kraju. Oprócz licznych wcześniejszych poczynań ${ }^{5}$, w styczniu 1964 roku Antoni Słonimski, Paweł Hertz, Paweł Jasienica, Stefan Kisielewski i Melchior Wańkowicz - wystąpili z ostrą krytyką działalności cenzury i polityki wydawniczej. W marcu tegoż roku Słonimski złożył w kancelarii premiera Cyrankiewicza podpisany przez trzydziestu czterech wybitnych pisarzy i uczonych list, wyrażający sprzeciw wobec polityki kulturalnej rządu, braku papieru na druk i coraz ostrzejszej cenzurze. Sam twórca wspominał w rozmowie z Witoldem Mieczysławskim o konsekwencjach podpisania listu:

Zadzwoniłem wtedy do Kotarbińskiego, Kotarbiński mi powiedział tak: „Niech Pan się tym bardzo nie przejmuje, ale niestety wszystko na Pana spada. Zakaz druku, publikacji itd." - Wydało mi się to po prostu śmieszne. Co znaczy zakaz druku? No i potem to się okazało. Pisywałem takie felietony zarobkowe w "Szpilkach”. Redaktor "Szpilek" zawiadomił mnie, że niestety, zakaz druku, nie możemy Pana drukować?

4 A. Słonimski, Wspomnienia warszawskie, Warszawa 1987, s. 78.

5 W roku 1953, podczas oficjalnej dyskusji, w której brał udział premier Józef Cyrankiewicz, Słonimski wystąpił z ostrą krytyką Zarysu literatury polskiej dla kl. II. Wraz z antologia poezji i publicystyki. Kolejny raz bardzo krytycznie wypowiedział się w roku 1955 podczas XV Sesji Rady Kultury i Sztuki. Wypowiedź dotyczyła centralizmu w życiu literackim i artystycznym. W kolejnym roku, 1956, w trakcie obrad XIX Sesji Rady Kultury i Sztuki, Słonimski zdecydowanie wystąpił przeciw lansowanej przez Włodzimierza Sokorskiego teorii kultu jednostki. W roku 1959 cały nakład recenzji teatralnych Słonimskiego pt. Gwałt na Melpomenie został wycofany ze sprzedaży i przekazany na przemiał - głównie z powodu wydrukowania recenzji sztuki Car Lenin.

6 Słonimski współpracował ze „Szpilkami” w latach 1960-1964, co tydzień publikując w nich felieton.

7 Wspomnienia o Antonim Stonimskim, red. P. Kądziela i A. Międzyrzecki, Warszawa 1996, s. 218-219. 
Dalej, we właściwy sobie, humorystyczny sposób podsumował:

Ten zakaz druku miał nawet dość zabawne aspekty, bo przed samym zakazem w jakimś miesięczniku rozrywkowym była krzyżówka. I kiedyś u dentysty z nudów rozwiązałem tę krzyżówkę - autor tytuł wiersza. Autorem wiersza był Antoni Słonimski, tytuł wiersza - Żal. Autor był pionowy, a tytuł był poziomy. W następnym numerze po miesiącu nie było rozwiązania tej krzyżówki, bo był już zakaz druku. Wszyscy, którzy odgadli tę krzyżówkę i mieli dostać aparat fotograficzny, zawiedli się, bo nie było ani rozwiązania, ani nikt żadnej nagrody nie dostał. Tylko ja zostałem poziomy zamiast pionowy ${ }^{8}$.

Niestety, w kolejnych słowach wesoły ton ustępował, a poeta wyznał: „Zakaz druku po pewnym czasie jest dla pisarza nieznośny. Człowiek się burzy. Zacząłem w jakiś dziecinny sposób szukać mego nazwiska, gdzie się mogło zjawić. Nigdzie go nie było"".

W lutym 1968 roku Słonimski przemawiał podczas zebrania ZLP w sprawie zdjęcia ze sceny Dziadów w inscenizacji Kazimierza Dejmka. Wypowiadał się o odchodzeniu od przemian Października 1956, przeprowadził również ostry atak na cenzurę. W marcu 1968 był sygnatariuszem wraz z Jerzym Andrzejewskim, Tadeuszem Konwickim, Melchiorem Wańkowiczem i Adamem Ważykiem listu zredagowanego przez Pawła Jasienicę do rektora Uniwersytetu Warszawskiego w sprawie zakazu wystawiania Dziadów i represji wobec studentów. Bezpośrednio po tych wydarzeniach w „Kurierze Polskim" ukazał się nad wyraz krytyczny artykuł wymierzony w Słonimskiego, a 19 marca Władysław Gomółka w swoim przemówieniu zaatakował m.in. Pawła Jasienicę oraz Słonimskiego. W obu oszczerczych tekstach stwierdzano, że jest „obcym elementem”, kosmopolitą i że nie jest Polakiem.

Słonimski był jeszcze sygnatariuszem dwóch listów skierowanych do władz PRL. W roku 1974 wraz z Adamem Michnikiem zainicjował podpisanie Listu 15, który dotyczył udostępnienia Polakom w ZSRR kontaktu z kulturą polską i dostępu Polonii do własnego szkolnictwa. Był to jeden z ważniejszych protestów polskiej inteligencji po 1968 roku. Na rok przed śmiercią,

8 Tamże, s. 219.

9 Tamże. 
która nastąpiła w 1975 roku, Słonimski podpisał kolejny - List 59, w sprawie projektowanych zmian w Konstytucji PRL.

Należy wspomnieć, że konsekwencjami poczynań Słonimskiego były nie tylko zapisy cenzorskie na jego nazwisko, lecz również działania Służby Bezpieczeństwa:

SB wyprodukowała 12 tomów akt dotyczących Antoniego Słonimskiego, czyli "Syzyfa" lub „Sajmona”, bo takie pseudonimy nadała poecie. Był traktowany szczególnie - prowadzono wobec niego system operacyjnego rozpracowywania, co w przypadku pisarzy zdarzało się rzadko. Zaangażowano wszelkie możliwe metody i techniki, nie wyłączając kosztownego "pp" - podsłuchu pokojowego. Pięć tomów akt to efekt działań operacyjnych wobec poety, trzy tomy pochodzą z biura "W", zajmującego się perlustracją korespondencji, kolejne trzy to plon podsłuchu, a jeden zawiera zapisy obserwacji1 ${ }^{10}$.

Działania Słonimskiego, po tym jak w 1951 roku na dobre wrócił do Polski, były pilnie obserwowane przez Główny Urząd Kontroli Prasy, Publikacji i Widowisk ${ }^{11}$. Zlokalizowane przy ulicy Mysiej „Ministerstwo Prawdy” wytworzyło szereg dokumentów, w których zawarto opinie na temat samego poety, jak i utworów jego autorstwa. Po śmierci Słonimskiego również skrupulatnie przeglądano proponowane do druku treści. Dowodem tych działań są przytoczone poniżej wyimki z dokumentów GUKPPiW, w których nazwisko Słonimskiego się pojawia.

Celem artykułu jest ukazanie stosunku GUKPPiW wobec Antoniego Słonimskiego, a także jego dzieł oraz ich recepcji od wczesnych lat 60 . aż do początku dziewiątej dekady XX wieku.

\section{Cenzura wobec Antoniego Słonimskiego}

Pośród kontrolowanych materiałów z Wydawnictwa „Iskry” oraz „Ludowej Spółdzielni Wydawniczej” z roku 1961 znajduje się poddany ingerencjom życiorys literacki Antoniego Słonimskiego ${ }^{12}$. Co ciekawe, w tym przypadku

10 J. Kuciel-Frydryszak, Heretyk na ambonie, s. 304.

11 Dalej: GUKPPiW.

12 AAN, GUKPPiW, sygn. 380, k. 223-224. 
GUKPPiW zdaje się cenzurować tekst zgodny z obowiązującą ideologią. Nie jest to sytuacja typowa, bowiem, jak wiadomo, najczęściej cięciom poddawane były materiały, których treść nie odpowiadała partyjnym wytycznym, otrzymywanym przez cenzorów kontrolujących teksty. Zaprezentowany poniżej materiał to biogram Antoniego Słonimskiego, zaproponowany do druku przez LSW w kalendarzu na rok $1962^{13}$. Podkreślenia pochodzą od cenzora.

$[k.] \underline{43}, 223,[-]$

wersja zakwestionowana: [dopisano odręcznie]

Antoni Słonimski

ur. 1895

[z boku dopisek:

wersja niedopuszczona do druku]

Syn znanego warszawskiego lekarza, trwałymi węzłami związany z naszą stolicą. Należał do grupy "Skamander”. Wspólnie z Tuwimem, Lechoniem i Wierzyńskim zakładał kabaret literacki „Pod Pikadorem”. Debiutuje w 1918 r. Już pierwsze jego wiersze zapowiadają wybitnego poetę. Cechował je liberalizm i pacyfizm. Napór faszyzmu w Polsce po przewrocie majowym pogłębił jego ideologię. W utworach swych Słonimski protestuje przeciwko imperializmowi, z nienawiścią mówi o niesprawiedliwości. Tułaczka wojenna poety dokonuje w nim ostatecznego przełomu. Słonimski - jak sam mówi - staje po stronie sprawy człowieczej, zwraca się do Ludu Warszawy o pozwolenie dotrzymania mu kroku. (Do czytelnika 1955 r.) Jest autorem wielu zbiorów wierszy, powieści i komedii, jak Wieża Babel, Murzyn warszawski, Lekarz bezdomny. Jego utwory nie tylko głęboko wzruszają, ale także uczą, zmuszają do myślenia. Wybór słynnych jego kronik tygodniowych z "Wiadomości Literackich” wznowiono po wojnie w wydaniu książkowym. W 1955 r. otrzymał Państwową Nagrodę Literacką.

13 Popularne wówczas były kalendarze zawierające m.in. dane statystyczne, artykuły o sztuce, architekturze, czy właśnie krótkie informacje biograficzne znanych osób. W kalendarzu na ten sam rok, wydanym nakładem Wydawnictwa Warszawskiego Tygodnika Ilustrowanego „Stolica”, pomieszczono aż 125 krótkich biogramów. Por. Kim kto jest? 125 warszawianek $i$ warszawiaków, [w:] Ilustrowany Kalendarz Warszawski 1962, Warszawa 1961, s. 49-103. 
Można przypuszczać, że życiorys w przytoczonej powyżej, pierwotnej wersji posiadał aż nazbyt widoczny propagandowy wydźwięk, a sama notka - zbliżała się do partyjnej nowomowy. Świadczą o tym podkreślenia - w ten sposób oznaczono fragmenty napisane tym charakterystycznym językiem. Jak się najwyraźniej okazało - na tyle charakterystycznym, że nie do przyjęcia nawet przez GUKPPiW. Można również przyjąć ostrożne założenie, że zastosowana w LSW stylistyka partyjnych przemówień miała na celu uśpienie czujności cenzora, a tym samym przemycenie do powszechnego obiegu nazwisk pozostających na emigracji i wrogo nastawionych do władz PRL Skamandrytów. W tekście dopuszczonym do druku zniknęły bowiem nazwiska objętych zakazem druku Lechonia i Wierzyńskiego. Co ciekawe, nie wykreślono jednak tytułu „Wiadomości Literackich” - pisma emigracyjnego. Cenzor nie omieszkał tu jednak dokonać znaczącej zamiany określenia kronik tygodniowych (ze „słynnych” na „dowcipne”). Nic dziwnego, że w kolejnej wersji krótkiego tekstu dokonano stosownych korekt:

[k.] 43, 224, [-]

wersja zrobiona do druku: [dopisano odręcznie]

Antoni Słonimski

ur. 1895

[z boku przekreślony dopisek:

wersjalldopuszczona do druku]

Syn znanego warszawskiego lekarza, trwałymi węzłami związany ze stolicą. Był współzałożycielem kabaretu literackiego „Pod Pikadorem” i członkiem grupy poetyckiej „Skamander”. Debiutuje w r. 1918 wydaniem tomiku liryków Sonety. Od 1924 r. jest stałym felietonistą i recenzentem teatralnym tygodnika "Wiadomości Literackie", gdzie zamieszcza swoje dowcipne Kroniki tygodniowe. W latach II wojny światowej przebywał na emigracji w Londynie. Redaguje tu miesięcznik "Nowa Polska”. Po wojnie brał z ramienia Polski udział w pracach UNESCO (Organizacja Narodów Zjednoczonych do Spraw Wychowania, Nauki i Kultury). W r. 1956 został prezesem Związku Literatów Polskich. Jest autorem wielu tomów liryków, poematów i wierszy (Czarna wiosna, Godzina poezji, Okno bez krat, Wiek klęski). Wydał tez kilka powieści i cieszących się swego czasu dużym powodzeniem komedii satyrycznych o antyfaszystowskiej wymowie (Wieża Babel, 
Murzyn warszawski, Lekarz bezdomny, Rodzina). W r. 1955 za swoją twórczość artystyczną otrzymał Słonimski Państwową Nagrodę Literackąi ${ }^{14}$

W wersji - jak to określił cenzor - ,zrobionej do druku” zostały usunięte podkreślone fragmenty, a całość poddano przeredagowaniu.

Kolejny przykład działań GUKPPiW wobec Słonimskiego pochodzi już z połowy lat 70. Nazwisko poety zostało bowiem ujęte w Ksiażce zapisów $i$ zaleceń GUKPPiW z 21 lutego 1976 roku $^{15}$. W dziale dotyczącym kultury wprowadzono „zapis” cenzorski na aż trzydzieści siedem nazwisk - wśród nich znajduje się Antoni Słonimski. Ich wykaz poprzedzała klauzula:

Wszystkie własne publikacje autorów z poniższej listy, zgłaszane przez prasę i wydawnictwa książkowe oraz wszystkie przypadki wymieniania ich nazwisk należy sygnalizować kierownictwu Urzędu, w porozumieniu z którym może jedynie nastąpić zwolnienie tych materiałów.

Zapis nie dotyczy radia i TV, których kierownictwo we własnym zakresie zapewnia przestrzeganie tych zasad. Treść niniejszego zapisu przeznaczona jest wyłącznie do wiadomości cenzorów.

Kolejny dokument dotyczący najwyraźniej dla urzędników „kłopotliwej” biografii to sporządzona w czerwcu 1976 roku, na niespełna miesiąc przed śmiercią poety ${ }^{16}$, „Informacja $\mathrm{nr} 44$ o bieżących ingerencjach”, zawierająca notatkę o skreśleniach w felietonie Słonimskiego pt. Sandaueryzm. Co ciekawe, w tekście tym zamieścił on między innymi krótkie podsumowanie swego literackiego biogramu. Nabrało ono szczególnego znaczenia w obliczu wypadku, w którym zaledwie kilka tygodni później Słonimski zginął. Widoczne poniżej podkreślenia są dziełem cenzora. Oznaczono w ten sposób usunięte fragmenty. W samym do-

1422 lipca 1955 roku Słonimski otrzymał Nagrodę Państwową I stopnia w dziedzinie literatury.

15 Dokument znalazł się pośród innych materiałów z lat 1974-1977, wywiezionych przez Tomasza Strzyżewskiego do Szwecji, a następnie opublikowanych w 1977 roku w „Aneksie” w Londynie oraz w drugoobiegowej Niezależnej Oficynie Wydawniczej w Polsce w Czarnej księdze cenzury PRL.

16 Notatkę cenzury datowano na 25 czerwca 1976 r., natomiast Słonimski zmarł wskutek obrażeń poniesionych w wypadku samochodowym 4 lipca tego samego roku. 
kumencie zastosowano tekst rozstrzelony, a także skróty, co pozwala przypuszczać, że istniała, bądź nadal istnieje ${ }^{17}$, rozszerzona wersja „Informacji nr 44...”:

Przyszły historyk literatury niemały będzie miał kłopot z rozszyfrowaniem licznych aluzji, podtekstów, powiązań i przemilczeń. Jako badacz wykopalisk, skrupulatny archeolog składać będzie musiał skorupy naszej pisaniny, aby nazwać gatunek i określić epokę. Zwłaszcza ważne są daty. [...] Moje daty są nie najgorsze. Nagrodę miasta Warszawy, komandorię i nagrodę literacką pierwszego stopnia [...] dostałem nie w czasach dogmatyzmu, a właśnie w okresie lat 1955-1958. Po tej dacie znalazłem się znów w naszej szkole życia na ławce nie opromienionej zbytnią życzliwością urzędową. [k. 220] Parokrotnie na egzaminach skarcono mnie za popełnione błędy i wpisywano do dziennika dwóję ze sprawowania. [...] W zawikłanym retrospektywnym obrazie zmagań literackich rozezna się niełatwo, dochodzi bowiem do takich paradoksów, jak próba skompromitowania mnie dziś przy pomocy tekstu sprzed ćwierć wieku, wyrażającego poglądy obecnie propagowane przez pismo, które ten tekst mi właśnie wypomniało. [...]

Wydaje mi się, że w obecnej sytuacji ważny jest b i l a n s o g ó l n y. Bilans postawy moralnej. [...] Mając jaki taki dorobek i częste dowody sympatii społeczeństwa, czy warto przejmować się brakiem recenzji, czy embargiem telewiziji. [...] Czy warto przypominać, jaką kto miał ciocię, jakiego wujka, czy protektora? Kto się podpisał pod jakimś protestem i pierwszy z przestrachem podpis wycofał? [...]

Rozmawiałem nie tak dawno z Sandauerem, dzwonił do mnie parokrotnie. [...] Mówił całkiem do rzeczy, ale oto życie nagle otworzyło przed nim nową nieodpartą pokusę. Mógł się wykazać. Porzucił martwe teksty biblijne i z pasją zabrał się do paru żyjących pisarzy. Herbert, Miłosz, Słonimski, Andrzejewski i paru młodych poetów dobranych do koloru. Lista bardzo na czasie. Oczywiście Sandauer udowodni raz jeszcze, że to czysty przypadek. Potrafi nie takie rzeczy udowodnić... ${ }^{18}$

W cztery lata po śmierci poety w „Tygodniku Powszechnym” nr 27 z 1980 roku zamieszczono niepublikowany wcześniej wywiad (a właściwie jego transkrypcję) pod tytułem $Z$ Antonim Stonimskim. Co ciekawe, tekst ten drukiem nie mógł ukazać się aż 6 lat, bowiem Wojciech Lelek i Andrzej

17 Niektóre dokumenty w GUKPPiW niszczono.

18 AAN, GUKPPiW, sygn. 3453, k. 219-220. 
Grocholski przeprowadzili go już w grudniu 1974 roku. Audycję zrealizowano na zamówienie Studenckiego Studia Radiowego w Warszawie „Radio Riviera", gdzie nadano jedynie fragmenty rozmowy. W pierwszej części rozmowy Słonimski wypowiadał się o swej twórczości, w której był „wierny młodzieńczemu wierszowi Credo, wyrażającemu to »co jest właściwie zawarte [...] w Karcie Narodów Zjednoczonych, w Deklaracji Praw Człowieka«"19. Skróty w tekście pochodzą od cenzora, podobnie jak podkreślenia oznaczające usunięte fragmenty:

[...] Niewątpliwie mam pewne zadowolenie $z$ tego utrzymania pewnej konsekwencji w poezji, i w felietonie, i w sztukach, których niestety nie znacie, bo one [...] nie były wystawiane w Polsce. Dwa miesiące temu byłem w Londynie na premierze mojej sztuki Lekarz bezdomny, którą tam grali. Grali też Rodzinę, komedię, która miała jedno z największych powodzeń w Dwudziestoleciu. No, ale są to zagadnienia podobieństw charakterów, tych ekstremów totalistycznych, co - jak zresztą Lipski pisał w „Dialogu” w dużym artykule o mnie, było w pewnym okresie odkrywcze, a potem stało się truizmem. [...]

[...] Piszę mniej wierszy niż pisałem. Jeśli teraz napiszę czasem wiersz, to jest to przygoda. Tak samo, jeżeli chodzi o teatr. Ja nie piszę dla teatru po prostu ze względu na to, że moje rzeczy dawne są zupełnie niecenzuralne, a jeśli chciałbym wyrazić to, co chcę dziś, też bym nie potrafił prawdopodobnie w ramach cenzury. $[\ldots]^{20}$

Kolejna część rozmowy dotyczyła stosunku Słonimskiego do młodej generacji poetów:

[...] muszę z przyjemnością stwierdzić: czytałem poemat Barańczaka, czytałem parę wierszy młodszych poetów - one mi są bliskie, oni bliżsi mojej konwencji, niż powiedzmy konwencji Przybosia dlatego, że jest to pokolenie poetów gniewnych, pokolenie, które ma jakąś opozycję, oni mają coś do przekazania.

Z chwilą, jeżeli ma pan coś do przekazania, chce pan, żeby to doszło do odbiorcy, szuka pan wtedy drogi zrozumiałej, staje się pan komunikatywny.

19 AAN, GUKPPiW, sygn. 3652, k. 57.

20 Tamże, k. 58. 
Dlatego oni są bliżsi tradycji weryfikacji polskiej, poezji, która była zawsze patriotyczna w taki czy inny sposób, albo walczyła o wolność tego kraju, albo walczyła z niewolą, albo z formami rządzenia. Więc ja jestem tutaj optymistą, jeżeli chodzi o najmłodsze pokolenie poetów, tak samo niektórych młodych prozaików.

Zresztą, mówiłem o tym na kongresie PEN-Clubów w Sztokholmie, miałem takie przemówienie na otwarcie, w którym mówiłem o tym, że w naszym kraju pisanie bez rymu, bez rytmu i bez sensu jest popierane, bo to nie stwarza niebezpieczeństwa [...], jeżeli ktoś pisze bez rymu, bez rytmu, a zwłaszcza bez sensu. Więc to dzisiejsze ożywienie młodego pokolenia jest pozytywne, jakbyśmy wracali do tego credo, zachowałem troszkę tego optymizmu z czasów, kiedy pisałem ten wiersz, o którym mówiliśmy na początku. [... $]^{21}$

W ostatniej części dokumentu urzędnik parafrazował wycięte fragmenty wywiadu:

Ponadto z tegoż wywiadu, kolejnych wypowiedzi A. Słonimskiego wyeliminowano: - stwierdzenie sugerujące, że „u nas ze względów również i politycznych” sport „narzuca się jako namiastkę” i „w ten sposób odwraca się uwagę” od życia intelektualnego;

- uwagę, iż „jest bardzo bolesne, że [...] się u nas nie drukuje Dzienników Gombrowicza ${ }^{22}$.

\section{Cenzura wobec twórczości Słonimskiego}

W dokumentach Zespołu Instruktażu, Ocen i Kontroli GUKPPiW z 1972 roku, wśród ocenianych przez siebie materiałów, definiowano: „grupę tematyczną z zakresu spraw krajowych [którą - M. B.] stanowią ingerencje dotyczące polityki kadrowej”. Jak się okazało, w tak nieoczywisty sposób zaszeregowano pisany charakterystycznym językiem felieton Słonimskiego. Zapis tekstem rozstrzelonym pochodzi od poety, a podkreślenie - od cenzora i oznacza wycięcie fragmentu $\mathrm{z}$ druku:

21 Tamże.
22 Tamże. 
O humorze piszą ludzie bez humoru, o nauce - pseudo-naukowcy, a o poezji krytycy, którzy jej nie lu bią. Literaturze przewodza ludzie, którzy jej wiele lat szkodzili i wbrew opinii zespołu redakcyjnego i środowiska literackiego, p. Drozdowski staje na czele „Poezji”, jak Putrament stanął na czele "Literatury” ${ }^{23}$.

Powyższy fragment pochodzi z felietonu pt. Daltoniści, zgłoszonego do „Tygodnika Powszechnego" z dnia 12 listopada 1972 roku.

W tym samym Zespole Instruktażu, Ocen i Kontroli sporządzono zbiorczą „Informację o ingerencjach dotyczących problemów ideologii i polityki w okresie 1 stycznia 1973 - 30 kwietnia 1974 roku". W specjalnej tabeli wzmiankowano nazwisko Słonimskiego, redakcję „Polskiego Radia” oraz podano informację, że dokonano jednej ingerencji ${ }^{24}$. Niestety dokument nie zawiera załącznika z ocenzurowanym tekstem. Podobnie, w kolejnym zbiorczym zestawieniu omawianego zespołu, tym razem poświęconym nieco enigmatycznemu tematowi Systemu zarzadzania gospodarka i problemów modelowych - ujęto w tabeli nazwisko Słonimskiego, podając redakcję „Tygodnika Powszechnego" i wzmiankując jedną ingerencję ${ }^{25}$. Nie załączono omawianego tekstu.

W drugiej połowie czerwca 1974 roku poddano cięciom recenzję wierszy Słonimskiego autorstwa Stanisława Barańczaka, charakteryzując ją jako „rozrachunkową":

Ingerencje dotyczące problematyki kulturalnej, miały na celu „wyeliminowanie powtarzających się sądów "rozrachunkowych”, dotyczących różnych dziedzin kultury. Z recenzji wierszy A. Słonimskiego (pióra S. Barańczaka) traktującej poezję jako „siłę będącą naturalną przeciwwagą oficjalnej ideologii” eliminowano stwierdzenia, mówiące o dewaluacji słów, „załganiu treści i języka” przez współczesnych demagogów ${ }^{26}$.

Do dokumentu nie dołączono pełnej treści recenzji.

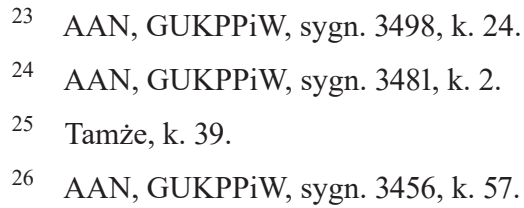


Kolejnym, zbiorczym dokumentem GUKPPiW była „Informacja o ingerencjach dokonanych w miesięcznikach »Więź« i »Znak« w okresie styczeń - wrzesień 1974". Jedna z ingerencji polegała na usunięciu fragmentu recenzji Obecności Słonimskiego:

Bardzo pozytywnej oceny doczekał się na łamach "Więzi” także Antoni Słonimski. Z zapisków Wiktora Woroszylskiego pt. Stąd i stamtąd w numerze 5/74 usunięto obszerny fragment, w którym autor, polemizując z krytyczną oceną książki A. Słonimskiego Obecność i roli tego pisarza w naszej literaturze (zaprezentowaną przez KTT na łamach "Kultury”) pisał m.in. o „mądrej, szlachetnej, imponującej OBECNOŚCl tego pisarza w zmaganiach o sztukę naszego wieku. I może także o coś, w czym sztuka jakoś się mieści, ale co jest większe, rozleglejsze, ogólniejsze od sztuki..."27

W kilka miesięcy po śmierci poety, 25 listopada 1976 roku, w „Tygodniku Powszechnym" nr 48 ocenzurowano fragmenty recenzji autorstwa R. Prawdzic pt. Testament Antoniego Stonimskiego. Tekst dotyczył Alfabetu wspo$m n i e n^{28}$, który wprawdzie w ośmiu miejscach poddany ingerencjom cenzury, ale jednak ukazał się nakładem PIW-u rok wcześniej. Podkreśleniami oznaczono fragmenty usunięte. Skrótów dokonano w urzędzie:

[...] Słonimski-satyryk i polemista ustępuje miejsca w Alfabecie wspomnień Słonimskiemu - ironiście i moraliście. [...] W krótki tekst wpisany tu został duży podtekst. Niedopowiedzenia jego i przemilczenia, prowadzić nas mogą ku szerokim, a zabarwionym ironią tragikomiczną, rozważaniom nad historiozofią i historią, a nawet - filozofią człowieka i ludzkiej egzystencji. [...]

Doceniając złożoność świata - wolał wypowiadać ją w sformułowaniach językowych pełnych prostoty i ładu, łączących lekkość, jasność i komunikatywność z kunsztem, logikę z paradoksem. [...] Dzisiaj, kiedy czesto watpi się w wartość słowa w ogóle, i to na całym świecie (produkt uboczny zwatpienia w to, że słowo było Bogiem?), liczne refleksje budzi jego wypowiedź o społecznym oddziaływaniu słów „Bez Mickiewicza, Wyspiańskiego i Żeromskiego nie byłoby Polski [...].

27 AAN, GUKPPiW, sygn. 3481, k. 268.

28 A. Słonimski, Alfabet wspomnień, Warszawa 1975. 
Warto przypomnieć młodym pisarzom [...], jaką słowo może mieć siłę i jaką pomoc nieść może narodowi. Jak bronić może godności, przywracać dumę..." [... $]^{29}$

Ze sprawozdania z działalności Zespołu Publikacji Nieperiodycznych GUKPPiW z 16 grudnia 1978 roku wynika, że w omawianym roku „skontrolowaniu" poddano ponad cztery tysiące tytułów. Większość z nich można było wydrukować - jednak w ponad trzystu przypadkach ,ingerencje okazały się konieczne", jak czytamy dalej:

Wśród kontrolowanych w 1978 r. publikacji były również i takie, do których zgłosiliśmy poważne zastrzeżenia i dlatego nie uzyskały zgody na druk. Były to pozycje, które naszym zdaniem nie zostały należycie ocenione w wydawnictwach, nie zostały właściwie przygotowane do rozpowszechnienia. Publikacje te, z przyczyn, o których piszemy w dalszej części sprawozdania, zwróciliśmy wydawnictwom do dalszego opracowania względnie zostały przez wydawnictwa wycofane z kontroli30.

Po powyższym wstępie wymieniono sześć tytułów - na pierwszym miejscu zbiór felietonów autorstwa Słonimskiego pt. Ciekawośc $c^{31}$. W dalszej części dokumentu znajduje się uzasadnienie:

Ponadto zgłosiliśmy, wynikające z określonych zapisów, zastrzeżenia do niektórych felietonów Antoniego Słonimskiego zgłoszonych do kontroli w formie książki pt. Ciekawość przez Sp. Wyd. „Czytelnik”. W felietonach przez nas kwestionowanych były wyrażone pozytywne, a nawet pochlebne opinie o T. Konwickim, S. Barańczaku, J. Bierezinie, A. Kisielu, Cz. Miłoszu, K. Bartoszewskim. Po zapoznaniu się z naszymi obiekcjami, wydawnictwo wycofało tytuł z Urzędu.

Zdaniem urzędu z ulicy Mysiej, przewinieniem Słonimskiego było pisanie o twórcach, których nazwiska budziły obiekcje cenzury, a czasem nawet objęte były konkretnymi ,zapisami”.

29 AAN, GUKPPiW, sygn. 3573, k. 97.

30 AAN, GUKPPiW, sygn. 3188, k. 2.

31 Kolejnych pięć: J. Andrzejewski, Nowe opowiadania; W. Materski, Polska a ZSRR 1923-25; M. Jantar, Po tamtej stronie nocy; S. Ozimek, W pustyni i Tobruku. Tamże, k. 3. 


\section{Cenzura wobec tematu śmierci Antoniego Słonimskiego}

Leopold Unger podawał, że 4 lipca 1976 roku, po śmierci Antoniego Słonimskiego, w GUKPPiW sporządzono następującą instrukcję:

W związku ze śmiercią Słonimskiego:

a) prasa drukować będzie wyłącznie komunikat PAP;

b) tylko jeden dziennik opublikuje nekrolog Ministerstwa Kultury i Sztuki oraz oficjalny komentarz (bez prawa przedruku);

c) prasa literacka ogłosi artykuły wyłącznie autoryzowane przez Komitet Centralny PZPR;

d) wszystkie wspomnienia i komentarze redakcyjne muszą być zaaprobowane przez Komitet Centralny ${ }^{32}$.

W myśl powyższej instrukcji, zaledwie trzy dni później - 7 lipca 1976 roku, cenzura usunęła z „Kuriera Polskiego” artykuł wspomnieniowy autorstwa Zagórskiego ${ }^{33}$ o Antonim Słonimskim. W dokumencie GUKPPiW przytoczono jego fragmenty. W tym wypadku, jak można przypuszczać, również istnieje rozszerzona wersja dokumentu. Świadczą o tym zastosowane w poniższym tekście skróty:

Odszedł ktoś, do kogo pasuje określenie Człowiek-Instytucja. Teraz, po śmierci, kiedy przestaje się liczyć tyle spraw, jak określić Go w sposób właściwy: imponująca osobowość, wielki pisarz, mocny duch, czułe serce, czy jasny umysł?

Był z pokolenia wzrosłego w zasadach ucieleśnionych przez Stefana Żeromskiego, któremu w późnym spadku po Romantykach przydawano tytuł: sumienie narodu. Słonimski należał do najbliższego kręgu przyjaciół i uczniów Żeromskiego. [...]

W najistotniejszych odruchach był rzetelnym poetą. Wiedział, że zaprzeczeniem poezji jest nuda i skostniałość. My zaś wiemy, że znamieniem poetów jest wybujała wrażliwość i ściśle związana z pobudliwością swoista krnąbrność, która

32 L. Unger, Intruz, Warszawa 2002, s. 249. Dalej Unger pisał, że wtedy zrozumiał ,jak prawdziwa była formułka przypisywana niegdyś byłemu premierowi Cyrankiewiczowi: »Trzy siły rządzą Polską - partia komunistyczna, Kościół katolicki i Antoni Słonimski«”. Tamże.

33 Prawdopodobnie mowa o Jerzym Zagórskim (1907-1984), choć w artykule widnieje inicjał A. Zagórski. 
bywa czasem niewygodna i kłopotliwa, lecz na ogół wychodzi światu na zdrowie.

Można było się z nim spierać w szczegółach doraźnej oceny, nikt mu jednak nie przeczył jasnego umysłu. [...]

Zostaje w historii, jako jeden z trzonowej piątki "Skamandrytów", wspaniały poeta o bardzo czystym stylu, znakomity felietonista i dramatopisarz, świetny satyryk, autor powiedzeń powtarzanych przez innych, jako cytaty. Zachwycał i gniewał, pouczał, polemizował, zaprzeczał i przytakiwał, rozjątrzał i rozbrajał. Był kimś, obok kogo nie można przejść obojętnie. Otwarty umysł, umiał forsować swoje zdanie, ale nie był głuchy na argument przeciwne. Oceniał ludzi, jak mawiał „per saldo”. Był wzorem humanisty i rycerza poczynań szlachetnych. [...]

Nigdy nie był przysłowiowym „letnim" z takich, co to ich wypluje Wieczność. Więc miał nie tylko przyjaciół, ale również antagonistów. Arena literacka jest areną także walk. Rozdawał i otrzymywał ciosy. Bez różnic w poglądach, nie byłoby postępu w myśli. [... $]^{34}$

Następnego dnia, 8 lipca 1976, w innym dokumencie GUKPPiW odnotowano, że ze „Słowa Powszechnego”: ,wyeliminowano - zgodnie z zaleceniem - nekrolog Antoniego Słonimskiego podpisany przez Zarząd Główny Związku Literatów Polskich"35. Nie załączono treści usuniętego nekrologu.

Nazajutrz, 9 lipca 1976, z 28. numeru „Życia Literackiego” znów wycięto w całości artykuł poświęcony Słonimskiemu. Jak podkreślono, uczyniono to „zgodnie z zaleceniem”. Zastosowany w tekście skrót pochodzi od cenzora:

[...] Antoni Słonimski stworzył swoim dorobkiem pisarskim własny i niepowtarzalny wzór osobowości, oparty o wartości racjonalistyczne, oparty na wierze w cywilizacyjny postęp, w możliwość porozumienia się ludzi dobrej woli, na równości społecznej i tolerancji. Wybitna inteligencja, przenikliwy dowcip, dawały jego opiniom charakterystyczny i nieporównany kształt, styl Słonimskiego. Jego poezja wyraziła uczucia i stany duchowe zrodzone z doświadczeń epoki. Literatura i kultura polska ponoszą z jego śmiercią niepowetowaną stratę ${ }^{36}$.

34 AAN, GUKPPiW, sygn. 3453, k. 383.

35 Tamże, k. 394.

36 AAN, GUKPPiW, sygn. 3564, k. 11. 
Tego samego dnia, 9 lipca 1976 roku, również w 28. numerze „Tygodnika Powszechnego", dokonano ingerencji cenzorskich, oznaczonych przez urzędnika podkreśleniem. Skrót pochodzi od cenzora:

[...] Był człowiekiem odważnym i prawym, oddanym do końca swych dni sprawie humanizmu w najlepszym tego ideału kształcie. Zawsze obecny tam, gdzie działa się krzywda, niesprawiedliwość, gdzie trzeba się było upominać o poszanowanie ludzkich spraw i ludzkich potrzeb. Stawał się gwałtowny i „niesprawiedliwy" tam, gdzie trzeba było walczyć z głupotą, zakłamaniem i obłudą. Ta gwałtowność i „niesprawiedliwość" brały się z potrzeby upominania się o prawa jednostki, jednostki zagrożonej w swej suwerenności wewnętrznej. Wiara w niezbywalną i wrodzoną godność człowieka, oraz płynące z niej konsekwencje dla życia indywidualnego i społecznego wycisnęła szlachetne piętno na wszystkim co pisał i czynił ${ }^{37}$.

Trzecim czasopismem, z którego 9 lipca 1976 roku usunięto materiał o Słonimskim, był tygodnik „Przekrój” (nr 28). Redakcja, po interwencji cenzury, wycofała własny tekst o poecie i zastąpiła go informacją PAP ${ }^{38}$. W dokumencie nie przytoczono wyciętej treści.

Ostatnim z dnia 9 lipca 1976 roku tekstem, ocenzurowanym ze względu na temat śmierci twórcy, był fragment zamieszczony w „Kurierze Polskim”. W całości usunięto z niego notatkę pt. Na cmentarzu w Laskach. Pogrzeb Antoniego Stonimskiego ${ }^{39}$. Do dokumentu GUKPPiW dotyczącego tej ingerencji nie dołączono jednak wyciętego tekstu bądź jego fragmentu.

W kilka tygodni po śmiertelnym wypadku Słonimskiego, po konsultacji z Wydziałem Prasy, Radia i TV KC PZPR, z „Polityki” (nr 33 z 13 sierpnia 1976 roku) w całości wyingerowano obszerny artykuł K. Koźniewskiego Niech trwa. Tym razem w materiałach cenzury zamieszczono zakwestionowaną treść. Autorem skrótów był urzędnik. Warto przywołać obszerny fragment:

37 Tamże, k. 16.

38 Tamże, k. 19.

39 Z tego samego numeru „Kuriera Polskiego” usunięto również cytat z Alfabetu wspomnień Słonimskiego, którego użył Zdzisław Skwarczyński w swojej książce pt. Stanisław Dygat. Ukazała się ona nakładem PIW-u w roku 1976, w ramach serii „Portrety współczesnych pisarzy polskich”. Nie załączono treści wykreślonego cytatu. Por. tamże, k. 18. 
W wypadku samochodowym zginął Antoni Słonimski, osiemdziesięcioletni pisarz polski.

Gdybym napisał, że zginął znakomity poeta - napisałbym prawdę niezupełną. Autor Alarmu, owego wiersza jak hymn z ust do ust powtarzanego w okupowanej, konspirującej, walczącej Warszawie - nie był poetą znakomitym. [...]

Gdybym napisał teraz, że zginął wybitny dramaturg lub komediopisarz - napisałbym tylko część prawy. Antoni Słonimski nie był wybitnym dramaturgiem. [...]

Mógłbym napisać, że w wypadku samochodowym został zabity wybitny prozaik - byłaby to prawda nader niedokładna. [...]

Powinienem był napisać, że w podwarszawskim Konstancinie zginął znakomity, wielki publicysta. Lecz wiem, że tym zgrzebnym, zbyt nikle w świadomości społecznej honorowanym, często deprecjonowanym i koślawionym określeniem obniżyłbym mimo woli rangę obywatelską pisarstwa Antoniego Słonimskiego.

Gdy chce się bowiem określić rolę Antoniego Słonimskiego w naszym życiu narodowym, społecznym, publicznym - trzeba użyć innego słowa. Nie poeta, nie dramaturg, nie publicysta - trzeba sięgnąć po określenie, jakie nasza społeczna tradycja przyznaje jedynie tym twórcom, który przekroczywszy domenę wyłącznie sztuki, wyłącznie artyzmu, stali się twórcami pewnych postaw obywatelskich, przestali być li tylko literatami - zostali pisarzami. Antoni Słonimski był - w tym właśnie rozumieniu - wielkim naszym pisarzem. Bodaj żadne inny język europejski nie zna tak wykreślonego rozróżnienia między literatem a pisarzem.

„Kroniki tygodniowe” od 1927 do 1939 roku regularnie zamieszczane w „Wiadomościach Literackich", może istotnie pomyślane początkowo jako jeszcze jedna domena satyryka, bardzo rychło stały się nie tylko najważniejszą pozycją publicystyczną tego literackiego tygodnika, ale jak gdyby szkołą lub kanonem postaw intelektualnych i moralnych dla bardzo wielkiej gromady czytelników wiodących się i z inteligencji warszawskiej, ze studentów oraz młodzieży postępowej. Autor „Kronik tygodniowych”, znienawidzony przez endecką i oenerowską prawicę, krytycznie i chłodno traktowany przez działaczy rewolucyjnej lewicy, był prawodawcą intelektualnym tej demokratycznej i liberalnej grupy naszej inteligencji okresu między wojennego, która coraz bardziej rozwijając się ku socjalizmowi, tworzyła naturalną otoczkę dla działaczy i działalności już wyraźnie rewolucyjnej. I która w końcu - konstytuując Stronnictwo Demokratyczne - zradykalizowała się naprawdę. Antoni Słonimski, który tyle pisarskiej energii włożył w walkę z brze- 
skim terrorem, w walkę przeciw Berezie, w walkę z rodzimymi przejawami faszyzmu, w walkę z antysemityzmem oenerowskiej młodzieży, który znalazł formułę, by mimo cenzuralnych trudności powiedzieć: nie zajęciu Zaolzia - ten Słonimski przez swoją "kronikarsko-tygodniową" publicystykę był ważnym animatorem postępowego, lewicowego ruchu ideowego i intelektualnego.

Alarm - wiersz wstrząsający współbrzmieniem z biciem polskich serc, serc ludu warszawskiego, ów wiersz, który przesłany z wojennej emigracji do Warszawy stał się niemal hymnem walczącego miasta, był dziełem, którego wartość daleko wykroczyła poza literaturę. To niezwykłe utrafienie w nastrój przeciętnego Polaka, w to co było uczuciową treścią naszego okupacyjnego patriotyzmu, zadecydowało właśnie o społecznej roli Alarmu, który już teraz w naszej literaturze znalazł się w ciągu utworów najściślej związanych z życiem narodu - z uczuć powszechnych zrodzony, uczucia te kształtujący. [...]

[...] To właśnie Antoni Słonimski założył w 1942 roku w Londynie pismo „Nowa Polska”, które stało się wyrazem postaw politycznych, opozycyjnych w stosunku do oficjalnej polityki rządu londyńskiego. To nie był żaden przypadek, ale owoc paroletnich przemyśleń, gdy w sierpniu 1945 roku Antoni Słonimski i Ksawery Pruszyński jako pierwsi pisarze polscy wrócili z Londynu do kraju, do Polski Ludowej właśnie. Ci dwaj, z których każdy miał później - jeden w 1951, drugi w 1976 - znaleźć śmierć w wypadku samochodowym - byli pierwszymi pisarzami emigracyjnymi akceptującymi Polskę Ludową. Antoni Słonimski jakby dwakroć wracał do Polski Ludowej po raz pierwszy w sierpniu 1945, gdy do Polski wrócił po wojnie, i po raz drugi w czerwcu 1951 roku, gdy do literatury Polski Ludowej wrócił po latach swych służb międzynarodowych, w UNESCO i w Londynie.

I zaraz po śmierci, i dziesiątki razy wcześniej, ci którzy pisali cokolwiek o Słonimskim, przytaczali jego sławne dwa wiersze: $W$ monarchii będę rewolucjonistą a w republice będę wielbił króla. Często i niesprawiedliwie przytaczano je, by tym autorskim wyznaniem charakteryzować jego przekorę intelektualną. I nie była to prawda: jeżeli pod słowem przekora, rozumiemy automatyczny odruch sprzeciwu wobec wszelkiej zastanej sytuacji - Słonimski nie był przekorny. W ten sposób pomniejszamy decyzję pisarza, który w sierpniu 1945 r. wybrał Polskę Ludową. W ten sposób pomniejszamy - ba! Przekręcamy! - decyzje pisarza, który tyle razy w swym życiu opowiadał się po stronie postępu, sprawiedliwości, humanitaryzmu, racjonalizmu, wolności. Słonimski nie był przekorny, a jeżeli nim był w latach swojej młodości - to później przekora ustąpiła miejsce najgłębszemu rozumieniu pew- 
nych racji moralnych, których chciał bronić, choćby nawet w kolizji z aktualnymi racjami i postulatami polityki państwa.

Nie należy tych spraw ukrywać, nie należy ich klajstrować dwuznacznymi przemilczeniami. Antoni Słonimski, który w decydujących momentach zawsze opowiadał się za Polską Ludową - nie należał do obywateli cichych i posłusznych. W codziennej naszej rzeczywistości nie raz i nie dwa razy głos jego brzmiał odmiennie. Nie zgadzaliśmy się ze Słonimskim w nie jednym [...]

[...] Słonimski nigdy jednak nie chciał taniej, byle jakiej jednomyślności, nie żądał jej od innych, nawet dla swoich własnych postulatów. Słonimski niekiedy nie miał racji - niekiedy tę rację miał. Słonimski mylił się. Słonimski wymagał sporu i dyskusji. Nie wolno go było bezkrytycznie przyjmować ani bezkrytycznie akceptować. Należało być Słonimskim wobec Słonimskiego. Znamieniem jego myśli pisarskiej nie była bezwarunkowa słuszność - tym znamieniem była odwaga posiadania własnego zdania. Często słusznego, czasem mylnego, ale zawsze własnego. Niekiedy słowo Antoniego Słonimskiego współbrzmiało z sercami milionów - ale zawsze było to jego słowo własne.

Dlatego nisko się pochyliwszy nad trumną tego polskiego pisarza rzucamy garść warszawskiej ziemi.

„Niech trwa"! 40

W parę miesięcy później, w miesięczniku „Więź”, w numerze 11. z listopada 1976 roku dokonano ingerencji cenzorskich we wspomnieniach Stefana Frankiewicza o Antonim Słonimskim pod tytułem I zaadresuj: Warszawa, jesień... Co ciekawe, tekst ten przedrukowano dwadzieścia lat później w książce Wspomnienia o Antonim Stonimskim, jednak zrobiono to, nie przywracając skreśleń cenzury ${ }^{41}$. W niniejszym artykule, w nawiasach kwadratowych oraz przypisach, zaznaczono różnice między tekstem zgłoszonym do GUKPPiW w 1976 roku a wydrukowanym w książce wspomnieniowej w roku 1996. Skróty w tekście Frankiewicza zostały wprowadzone w GUKPPiW. Również podkreślenia są dziełem cenzora, oznaczają fragmenty usunięte. Jeden z nich dotyczył wizyty autora w mieszkaniu Słonimskiego:

\footnotetext{
40 AAN, GUKPPiW, sygn. 3566, k. 1-2.

41 Por. Wspomnienia o Antonim Stonimskim, s. 25-29.
} 
[...] Zaczęliśmy rozmowę [oczywiście] ${ }^{42}$ od Lieberta i jego listów, w których tak wiele razy powraca Słonimski, nazywany tam po prostu Tolkiem. Ale rychło, po wesołym skomentowaniu kilku zabawnych obrazków odmalowanych w listach [...] mój rozmówca nagle spoważniał, posmutniał. Skończyło się wspominanie [tylko] ${ }^{43}$ tamtych czasów, Lieberta, do którego wielokrotnie wracaliśmy w czasie następnych spotkań. Zaczęła się długa rozmowa o dziśs4 ${ }^{44}$ Patrząc wtedy na smutek gospodarza pomyślałem, że rzeczywiście poetą jest się zwłaszcza dla innych, nie dla siebie, że najlepsze wiersze Słonimskiego, już te z początków lat trzydziestych, były zawsze reakcją poety na przeróżne zagrożenia i biedy zbiorowe, wyrazem niezgody i protestu wobec zastanego świata, a ich powstawaniu towarzyszyć musiało to samo ${ }^{45}$ zatroskanie, które widoczne było na twarzy mojego rozmówcy podczas tego wiosennego spotkania. [... $]^{46}$

Drugi ocenzurowany fragment dotyczył spotkań w warszawskiej kawiarni Ujazdowska:

[...] Charakterystyczny gest, którym już w progu witał przyjaciół w kawiarni „Ujazdowskiej": potrząśnięcie wysoko w górze plikiem gazet - stanowił jakby zapowiedź tego, co otwierało niemal każde spotkanie, a mianowicie serwisu najświeższych wiadomości i komentarzy do nich. Kilkakrotna w ciągu dnia celebra słuchania radia i skrupulatna lektura gazet, dawały to, że wystarczyło wpaść o 11.30 do „Ujazdowskiej”, by poddawszy się temu swoistemu „swobodnemu przepływowi informacji” 47 dowiedzieć się od razu wszystkiego. [...] Pamiętam, wracaliśmy kiedyś z kawiarni Alejami Ujazdowskimi po rozmowie, w której było przede wszystkim bezradne ${ }^{48}$ milczenie i zrozumiałe wtedy $\underline{49}$ przygnębienie. Młodszy od niego o pół wieku, lazłem jak starzec, przerywając ciszę

\footnotetext{
42 Słowo pojawiło się dopiero w przedruku. Por. Wspomnienia o Antonim Słonimskim, s. 25.

43 Słowo pojawiło się dopiero w przedruku. Por. tamże.

44 Brak w przedruku.

45 Brak w przedruku.

46 AAN, GUKPPiW, sygn. 3572, k. 327.

47 Brak w przedruku.

48 Brak w przedruku.

49 Brak w przedruku.
} 
banalnymi uwagami na temat pogody i gołych grudniowych ${ }^{50}$ drzew. Mój towarzysz, po staremu trzymając ręce sztubacko w kieszeniach, szedł tym razem, jak mi się wydawało, krokiem jeszcze bardziej zdecydowanym, pewnym, szybciej niż zazwyczaj. I wtedy pomyślałem sobie, że nawet ludzie z bliska obserwujący Antoniego Słonimskiego widzieli w nim przede wszystkim znaną nie tylko pod polskim niebem poważną instytucjęㄴ naszego życia społecznego, której sprawne działanie gwarantowały jak w dobrym szwajcarskim zegarku najwyższej jakości mechanizmy, obracające się od półwiecza niezmiennie, regularnie, tak samo. Rosnąca do końca instytucjonalizacja $\underline{52}$ tej postaci przesłoniła nam pewnie człowieka, który jednak, mimo owego półwiecza, uczył się wiąż podejmowania wyborów, zwyczajnej sztuki przegrywania i też zwyczajnego cieszenia się wielkim i małym. $[\ldots]^{33}$

\section{Zakończenie}

Przytoczone przykłady ukazują strategie działań cenzury wobec Słonimskiego. Co ciekawe, w tym wypadku najbardziej kontrowersyjne $-\mathrm{z}$ punktu widzenia GUKPPiW - nie były dzieła pisarza, lecz jego postać. Widać to zwłaszcza w materiałach z 1976 roku, już po śmierci autora Alarmu. W związku z obowiązującym wcześniej ,zapisem” na poetę, zezwolono bowiem jedynie na przedrukowywanie komunikatu PAP. Ilustracją stosunku cenzury do Słonimskiego są z pewnością typy wprowadzanych ingerencji - twórcę postrzegano jako postać niepożądaną, kontrowersyjną, której odważnych działań - choćby w walce o wolność słowa w Polsce - nie powinno się przypominać. Wzmianki w tekstach - potencjalnie odnoszące się do kontekstu politycznego - usuwano. Cenzurowano bardzo drobiazgowo: wycinano pojedyncze słowa lub całe zdania, a gdy nie dało się ,zneutralizować” wymowy tekstu w ten sposób - nie zezwalano na druk całości. W ten sposób, niestety, wydatnie przyczyniono się do zubożenia recepcji Słonimskiego.

50 W przedruku: ,gołych zimowych drzew”. Por. Wspomnienia o Antonim Stonimskim, s. 26.

$51 \quad$ W przedruku: ,postać”. Por. tamże.

52 W przedruku: słowo ,instytucjonalizacja” ujęte zostało w cudzysłów. Por. Wspomnienia o Antonim Stonimskim, s. 26.

53 AAN, GUKPPiW, sygn. 3572, k. 327. 


\section{Bibliografia}

\section{Literatura cytowana}

Andrzejewski J., Nowe opowiadania, Warszawa 1980.

Czarna księga cenzury PRL, wyb. T. Strzyżewski, Londyn 1977.

Ilustrowany Kalendarz Warszawski 1962, Wydawnictwo Warszawskiego Tygodnika Ilustrowanego „Stolica”, Warszawa 1961.

Kuciel-Frydryszak J., Heretyk na ambonie, Warszawa 2012.

Materski W., Polska a ZSRR 1923-1924, Wrocław 1981.

Ozimek S., W pustyni i Tobruku, Warszawa 1982.

Skwarczyński Z., Stanisław Dygat, Warszawa 1976.

Słonimski A., Gwałt na Melpomenie, Warszawa 1959.

Słonimski A., Wspomnienia warszawskie, Warszawa 1987.

Unger L., Intruz, Warszawa 2002.

Wspomnienia o Antonim Słonimskim, red. P. Kądziela i A. Międzyrzecki, Warszawa 1996.

\section{Materiały archiwalne}

AAN, GUKPPiW, sygn. 380.

AAN, GUKPPiW, sygn. 3188.

AAN, GUKPPiW, sygn. 3453.

AAN, GUKPPiW, sygn. 3456

AAN, GUKPPiW, sygn. 3481.

AAN, GUKPPiW, sygn. 3498.

AAN, GUKPPiW, sygn. 3564

AAN, GUKPPiW, sygn. 3566.

AAN, GUKPPiW, sygn. 3572.

AAN, GUKPPiW, sygn. 3573.

AAN, GUKPPiW, sygn. 3652. 
隆 